\title{
A Comparative Study of Oxytocin \& Misoprostol in Active Management of Third Stage of Labour
}

\author{
Ansari $N^{1}$, Das $C R^{2}$
}

\begin{abstract}
Introduction: The third stage of labour is the period which follows the completed delivery of the foetus and consists of delivery of the placenta and its attached membranes. Aims and objectives: Comparison of oxytocin \& misoprostol in active management of third stage of labour. Material and Methods: This is a comparative cross-sectional study was conducted in Nepalgunj Medical College Teaching Hospital, Kohalpur from March 2013 to March 2014. Group A - Oxytocin 10 IU IV bolus in 100 patients and Group B Misoprostol 600 micro gram rectally. The collected were subjected to statistical analysis using SPSS 15. Results: After active management with bolus oxytocin, the blood loss was grossly reduced being $40-100 \mathrm{ml}$ in $84 \%$ cases and only $7 \%$ had blood loss more than $100 \mathrm{ml}$. blood loss between $200-300 \mathrm{ml}$ were only $6 \%$ and only $3 \%$ had PPH, after misoprostol $80 \%$ of cases had blood loss within 40-100 ml., 6\% cases had blood loss within 100-200 ml. and larger amount of blood loss i.e. between 200-300 ml. was observed in $7 \%$ cases, in $3 \%$ cases blood loss was between $300-400 \mathrm{ml}$. and $4 \%$ of women in this group had PPH. Conclusion: There was no statistically significant difference in the efficacy of oxytocin and misoprostol in reducing amount of blood loss and duration of labour in $3^{\text {rd }}$ stage of labour.
\end{abstract}

Keywords: Active management, misoprost, oxytocin, postpartum haemorrhage

\section{INTRODUCTION}

The third stage of the labour is the period which follows the completed delivery of the foetus and consists of delivery of the placenta and its attached membrane. During this stage a normal case can within a minute, become abnormal and successful delivery can turn swiftly to disaster. PPH is one of the most important causes of maternal mortality. There is a global program to prevent PPH by active management of $3^{\text {rd }}$ stage of labour.

There are two quite different approaches to the clinical management of third stage i.e. Physiological Management and active management, and these have been the subject of a number of critical reviews ${ }^{1,2,3,4}$. Physiological Management involves waiting for signs of separation and allowing the placenta to deliver spontaneously or aided by gravity or nipple stimulation. In contrast, in active management the clinician chooses to intervene in this process by using the following interlocking intervention: (i) administration of prophylactic oxytocin after delivery of the baby, (ii) early cord clamping and cutting and ( iii ) controlled cord traction of the umbilical cord.

Globally obstetrics haemorrhage is found to be main cause of maternal death. It has been estimated that at least $25 \%$ of

1. Dr. Nazmussaba Ansari

2. Prof. C. R. Das

Address of correspondence:

Dr. Nazmussaba Ansari

Department of Obst. \& Gynae.

Nepalgunj Medical College, Teaching Hospital, Kohalpur, Banke

Email: drnazmussabaansari@gmail.com these deaths are due to obstetrics haemorrhage. The majority due to post partum haemorrhage. This study was done therefore to compare the efficacy of oxytocin IV bolus and misoprostol in active management of third stage of labour (AMTSL).

\section{MATERIAL AND METHODS}

This is a comparative cross- sectional study conducted in Nepalgunj Medical College Teaching Hospital, Kohalpur in the department of Gynaecology and Obstetrics from March 2013 to March 2014. All the patients fulfilling inclusion criteria were divided in Group A - Oxytocin IV 10 IU was administered to 100 patients. Group B - Misoprostol 600 micro grams rectally was administered in 100 patients. The blood loss was collected and measured by measuring cylinder. All the data were entered in SPSS version 15 and were used descriptive and analytical study.

\section{RESULTS}

\begin{tabular}{|c|c|c|c|c|}
\hline \multirow{2}{*}{$\begin{array}{c}\text { Age of patient } \\
\text { (Years) }\end{array}$} & \multicolumn{4}{|c|}{ Study Group } \\
\cline { 2 - 5 } & \multicolumn{2}{|c|}{$\begin{array}{c}\text { Group A } \\
\text { Oxytocin }\end{array}$} & \multicolumn{2}{c|}{$\begin{array}{c}\text { Group B } \\
\text { Misoprostol }\end{array}$} \\
\cline { 2 - 5 } & No & $\%$ & No & $\%$ \\
\hline $18-25$ & 15 & 15 & 18 & 18 \\
\hline $26-30$ & 41 & 41 & 30 & 30 \\
\hline $31-35$ & 35 & 35 & 39 & 39 \\
\hline $36-40$ & 9 & 9 & 13 & 13 \\
\hline
\end{tabular}

Table I: Distribution of patients according to age 
Mean age: In group A, it was 30.28 and in group $B$, it was 29.78 . Standard deviation in Group A was 5.54 and in group B, it was 4.95 .

\begin{tabular}{|c|c|c|c|c|}
\hline \multirow{2}{*}{ Parity } & \multicolumn{2}{|c|}{ Group A } & \multicolumn{2}{c|}{ Group B } \\
\cline { 2 - 5 } & \multicolumn{2}{|c|}{ Oxytocin } & \multicolumn{2}{c|}{ Misoprostol } \\
\cline { 2 - 5 } & No & $\%$ & No & $\%$ \\
\hline Nullipara & 30 & 30 & 26 & 26 \\
\hline Primipara & 23 & 23 & 29 & 29 \\
\hline $2^{\text {nd }}$ para & 21 & 21 & 18 & 18 \\
\hline $3^{\text {rd }}$ para & 12 & 12 & 15 & 15 \\
\hline Para 4 and above & 14 & 14 & 12 & 12 \\
\hline
\end{tabular}

Table II: Distribution of patients according to parity

Nullipara were maximum in Group A i.e. $30 \%$ where as primipara were maximum in Group Bi.e. $29 \%$.

\begin{tabular}{|c|c|c|c|c|}
\hline \multirow{2}{*}{$\begin{array}{c}\text { Duration of 3 } \\
\text { stage (mins.) }\end{array}$} & \multicolumn{2}{|c|}{ Group A } & \multicolumn{2}{c|}{ Group B } \\
\cline { 2 - 5 } & \multicolumn{2}{|c|}{ Oxytocin } & \multicolumn{2}{c|}{ Misoprostol } \\
\cline { 2 - 5 } & No & $\%$ & No & $\%$ \\
\hline $3-5$ & 42 & 42 & 33 & 33 \\
\hline $5-7$ & 30 & 30 & 31 & 31 \\
\hline $7-9$ & 18 & 18 & 23 & 23 \\
\hline $9-11$ & 5 & 5 & 3 & 3 \\
\hline $11-13$ & 3 & 3 & 5 & 5 \\
\hline $13-15$ & - & - & 2 & 2 \\
\hline$>15$ & 2 & 2 & 3 & 3 \\
\hline
\end{tabular}

Table III: Distribution of patients according to the duration of $3^{\text {rd }}$ stage of labour.

Maximum patients were delivered in $3-5$ minutes duration in both the groups.

\begin{tabular}{|c|c|c|}
\hline \multirow{2}{*}{$\begin{array}{c}\text { Statistical } \\
\text { Parameters }\end{array}$} & Group A & Group B \\
\cline { 2 - 3 } & Oxytocin & Misoprostol \\
\hline Mean Duration & 4.48 & 4.93 \\
\hline $95 \% \mathrm{Cl}$ & $4.17-4.78$ & $4.52-5.34$ \\
\hline Median & 4.00 & 4.00 \\
\hline Standard Deviation & 1.53 & 2.06 \\
\hline
\end{tabular}

Table IV: Statistical analysis of distribution of subjects in two groups according to duration (min.)

\begin{tabular}{|c|c|c|}
\hline $\begin{array}{c}\text { Statistical } \\
\text { Parameters }\end{array}$ & Group A & Group B \\
\cline { 2 - 3 } Mean blood loss & Oxytocin & Misoprostol \\
\hline $95 \% \mathrm{Cl}$ & 81.00 & 91.04 \\
\hline Median & $60.53-101.47$ & $74.88-107.20$ \\
\hline Standard Deviation & 103.17 & 60.00 \\
\hline
\end{tabular}

Table V: Distribution of subjects in two groups according to loss of blood (ml.)

\section{DISCUSSION}

The present study was conducted on 200 patients, a comparison of Oxytocin \& Misoprostol in active management of third stage of labour. Out of which bolus 10 IU oxytocin was given to 100 cases while 600 mcg of misoprostol was inserted rectally in second group of 100 cases.

1. Age - Among patients of oxytocin group, the youngest patient was of 19 year and the oldest patient aged 40 year with a mean age of 30.28 year and SD of 5.54 . In group Bi.e. misoprostol group, highest number of cases were from 31 35 year of age. In this group age of different patients ranged from $18-40$ year with a mean age of 29.78 with SD of 4.95. No statistical significance was observed between the ages of two groups of patients is comparable with other studies Walter J et al. (1988) ${ }^{5}$ and J Rogers et al. $(1998)^{6}$

2. Parity - In the present study. In oxytocin group, nulliparaous were $30 \%$ and primipara were $23 \%$ while in misoprostol group nulliparous were only $26 \%$ and primipara were $29 \%$. In oxytocin group $14 \%$ were grand multipara while in misoprostol group number of grand multipara were almost similar to oxytocin group (12\%). In Bristol third stage trial, Walter J et al. ${ }^{5}$ have reported the number of primipara being 372 in Physiological Management group and 409 in active management group. While Eray Clistkan et al. (2003) ${ }^{7}$ in their study have reported the incidence of primipara $46.6 \%$, multipara $52.3 \%$ and grand multipara being $1 \%$ in misoprostol group while in oxytocin group $52.3 \%$ were primipara, $49.4 \%$ were multipara and grand multipara was only $1 \%$.

3. Duration of third stage of labour- In the study group A, it varied from 3.25 to 16.5 min with mean of 4.48 and study group B it ranged from 3.42 to 16.55 min with mean of 4.93. On statistical comparison, however, no significant difference was observed between two study groups. Eray Caliskan et al., $2003^{7}$ in their study compared misoprostol (400 mcg orally) with 10 IU oxytocin in 500 ml. of Ringer lactate and observed slightly longer mean duration of third stage of labour in misoprostol group ( $9.2 \mathrm{~min}$ ) as compared to after IV oxytocin (8.7 $\mathrm{min})$. 
4. Blood loss in $3^{\text {rd }}$ stage of labour- In oxytocin group and misoprostol group reduced amount of blood loss was observed.

Shekharan et al. (2007), have advocated oxytocin as the drug of choice in active management of third stage of labour as it has rapid onset of action and does not increase the risk of retained placenta. Rogers et al. ${ }^{6}$ have also reported enormously reduced incidence of PPH after active management (6.8\%) as compared to those who were managed Physiological Managemently (16.5\%). Prendiville et al. ${ }^{8}$ in Cochrane review (2000), have strongly advocated that routine active management is superior to Physiological Management in terms of blood loss, PPH and other serious complications of third stage of labour.

\section{CONCLUSION}

The amount of blood loss in $3^{\text {rd }}$ stage of labour was found to be grossly reduced to $81.00 \pm 103.17 \mathrm{ml}$ in oxytocin group and $91.04 \pm 79.74 \mathrm{ml}$ in misoprostol group $(p<0.001)$ after active management both by oxytocin and misoprostol which is not significant. The duration of $3^{\text {rd }}$ stage of labour was found to be grossly reduced. The duration of Oxytocin group is $4.48 \mathrm{~min}$ and $4.93 \mathrm{~min}$ in Misoprostol group $(p<0.001)$ after active management both by oxytocin and misoprostol which is not significant. Active management of labour reduced the amount of blood loss in both the group. Active management of $3^{\text {rd }}$ stage of labour is advocated as a routine to prevent PPH and such maternal mortality. Therefore there was no statistically significant difference in efficacy of oxytocin and misoprostol.

\section{REFERENCES}

1. Elborne DR. Active vs conservative $3^{\text {rd }}$ stage management- low risk women. [revised 01 April 1993 ] In: Enkin MW, KeirseMJNC, Renfrew MJ, Neilson JP, Crowther C (eds.) Pregnancy and childbirth Module. In: The Cochrane Pregnancy and childbirth Database [database ondisk and CDROM]. The Cochrane collaboration; Issue 2, Oxford: Update Software; 1995.

2. Gyte G. The significance of blood loss at delivery. MIDIRS midwifery Dig 1992;2(1):88-92.

3. Prendiville WJ. The prevention of post partum haemorrhage: optimizing routine management of the third stage of labour. Eur J Obstet Gynecol Reprod Biol 1996;69:19-24.

4. Prediville WJ, Elbourne DR. Care during the third stage of labour. In: Chalmers I, Enkin M, Keirse MJNC editor(s). Effective care in pregnancy and childbirth. Oxford University Press, 1989:1145-69

5. Prendiville WJ, Harding JE, Elbourne DR, Stirrat GM. The BRIstol third stage trial: active vs physiological management of third stage of labour. BMJ 1988;297:1295-300.

6. Rogers J, Wood J, McCandlish R, Ayers S, Truesdale A, Elbourne D. Active versus Physiological Management management of third stage of labour: the Hinchingbrook randomized controlled trial. Lancet 1998;351:593-9.
7. Caliskan E, Dilbaz B, Meydanli M, Ozturk N, Narin M, Haberal A. Oral misoprostol for the third stage of labour : a randomized controlled trial. Obstetrics \& Gynecology 2003;101:921-8.

8. Prendiville WJP, Elbourne D, McDonald SJ. Active versus Physiological Management management in the third stage of labour. Cochrane Database of systematic Reviews 2000, Issue 3. Art no.: CD000007. DOI: 10.1002/14651858.CD000007. 